\title{
A National Study of Training Content and Activities for Faculty Development for Online Teaching
}

\author{
Katrina A. Meyer \\ Professor of Higher Education \\ University of Memphis \\ Vicki S. Murrell \\ Department of Counseling, Educational Psychology and Research \\ University of Memphis
}

\begin{abstract}
This article presents the results of a national study of 39 higher education institutions that collected information about their practices for faculty development for online teaching and particularly the content and training activities used during 2011-2012. This study found that the most frequently offered training content (97\% of the institutions) was assessment of student learning; followed by creating online community (91.1\%); and training on the institution's CMS, student learning styles, and instructional design models (all at 84\%). Most frequent training activities (over $90 \%$ of institutions) were workshops, one-on-one training opportunities, short sessions, hands-on training, one-time training, and creating an online course. Interesting differences by Carnegie institution type were found. These differences are perhaps explained by developers placing more value on teaching pedagogies than tools.
\end{abstract}

\section{INTRODUCTION}

How are higher education institutions providing faculty development for online teaching? What topics or content are they including? How is the training offered? And, perhaps most important, which of the training content and practices are valued by the institutions? These are the questions that guided a national survey of higher education institutions regarding faculty development for online teaching efforts. In short, this study provides a baseline of what is happening around faculty development for online teaching during the 2011-12 academic year, a baseline against which institutions can evaluate their current offerings, refine their practices, and assess new topics.

Faculty development plays an essential role in the Sloan Consortium's [2] five pillars of quality for online learning. One of those pillars is faculty satisfaction, which stresses the importance of faculty satisfaction with the online teaching experience and emphasizes commitment to improving online courses. Sloan-C characterizes faculty satisfaction as resulting from institutional support (also rewards and involvement in governance), which in turn is defined as the opportunity for "training in online instructional skills" [1,5]. Thus, faculty development in online teaching is a critical foundation for quality online education - a foundation that justifies the creation of an advisory panel of practitioners and researchers focused on faculty satisfaction, development, and support (http://sloanconsortium.org/jaln_advisory_panel_fs).

A critical first step in undertaking this work was to identify the current state of knowledge for faculty development for online teaching, which was reported in [1] The second and third steps are to collect relevant data from a national sample of institutions, and to report findings in various articles with a focus 
on relevant theories used in faculty development, cost assessments of training, preferred outcome measures, and challenges faced by these faculty developers. As a result, this article will provide a comprehensive picture of current faculty development for online teaching content and practices.

\section{REVIEW OF LITERATURE}

\section{A. Faculty Development}

\section{Training Activities}

In preparation for this study, a thorough review of the research literature on faculty development for online teaching was conducted; several journals (including $J A L N$ ) that publish such research were included in the search for relevant articles. Articles were included if they provided sufficient detail on the content and practices involved in faculty training. These articles included a wide range of training characteristics and activities. For example, training activities were differentiated based on the amount of time (number of hours, days, weeks, terms) spent in the training event, the number of individuals involved (one, small groups, larger sessions), and type of activity (from webinars to peer mentoring).

The most popular format for faculty development for online teaching appears to be the one-time, face-toface workshop or seminar [3, 4, 5, 6, 7], followed by the semester-long course [8, 9], and finally the multi-semester training initiative (up to one year in length) [10]. Some additional online alternatives to these formats include online courses [11], online modules, or webinars [9, 11]. Training can be offered in several fashions - one popular option is holding sessions in computer [laboratories with instructor demonstrations and/or opportunities to practice new skills [5, 12]. Training itself can be offered in oneon-one settings [6, 7, 13], to small and/or large groups, and across multiple institutions [14]. Similarly, training can draw upon the expertise of the faculty development expert (the majority of programs), a development team [15], an advanced faculty member or peer [4, 6, 7], or a mentor [13]. Perhaps the most common training activity for faculty is the design and development of an online course, especially one that the faculty will teach in the near future $[4,6,15,16,17,18]$.

Herman [21] recently collected faculty development information from 191 institutions and provided frequencies for faculty development program types. The most popular types included course management systems (90.4\%), online seminars (85.7\%), consultation with instructional design experts (84.2\%), workshops less than four hours in length (83.1\%), peer review of a designed course (75.0\%), multiple day workshops (63.8\%), expert review of online courses (57.4\%), and external options (44.0\%). In fact, there seem to be a large number of formats for providing faculty development which differ by length of time, type of activity (workshop, course design), training content, and number of individuals involved.

\section{Training Content}

The articles reviewed in preparation for this study describe a wide range of training content, which can be categorized into five broad groups: 1) basic uses of the course management system (CMS); 2) technological tools (e.g., wikis, blogs); 3) appropriate pedagogies originally used in the face-to-face classroom but applied to online learning; 4) online resources; and 5) instructional design principles or models. These content groups are detailed next and include appropriate references to specific articles.

Perhaps the most frequently mentioned content for faculty development programs in online teaching is the manipulation of the course management system (CMS) - e.g., Blackboard, Angel, or other software [3, $10,14,18]$. The contents of training often deals with tools, especially popular Web 2.0 tools (wikis, blogs), mobile technologies (iOS, Android, etc.) and social networking programs (Twitter, Facebook) [7, $10,12,13,17,22]$. Training may also deal with pedagogies related to developing community and worthwhile online discussions $[5,10,14,15]$, the implementation of active learning strategies [10, 15, 18], problem-based learning [7, 23], experiential learning [24, 25], etc. Depending on the discipline of the course being developed and the availability of already-developed materials, a popular topic for faculty development may be identifying, modifying, and embedding online resources or materials developed 
elsewhere [5, 6, 7, 12, 25]. Further, some faculty development programs go beyond the sharing of pedagogies to the direct teaching of instructional design models - -i.e., determining objectives, designing paths for learning, assessment of learning, etc. [4, 12, 26, 27, 28]. Finally, despite being mentioned rarely, some faculty development efforts strive to share with faculty the latest research or best practices in online learning $[13,17]$.

The articles on faculty development for online teaching also mentioned several other content areas, such as information about current student characteristics and institutional policies. Because these types of content areas are more general and likely suitable for training provided to any and all faculty, they were not deemed exclusively relevant to online teaching and were excluded from the analysis.

\section{Differences by Carnegie Classification}

Higher education institutions in the United States are classified into like groupings (http://classifications.carnegiefoundation.org/) based on work originally completed in 1973 by the Carnegie Foundation for the Advancement of Teaching. Institutional classifications have regularly evolved as criteria have been revised to address changes in higher education, accommodate the development of new types of institutions, or to better capture the diversity of institutions. The Carnegie classification has been a useful tool for higher education researchers and has been used in research covering a wide range of topics, including funding differences by Carnegie type, differences in faculty qualifications and roles, information technology needs and uses, etc. In fact, differences by Carnegie types are found in Herman's [21] study of faculty development programs for online instructors. Herman found a majority of programs (69.9\% of doctoral/research institutions and $57.4 \%$ of baccalaureate institutions) provide internally run training courses. Similarly, Herman found $63.4 \%$ of public institutions offer informal mentoring opportunities as compared to only $39.6 \%$ of private institutions. Carnegie classifications are instrumental in understanding differences in the use of institutional websites [29, 30, 31, 32] - i.e., Carnegie institutions may have more or less funding or staff to provide support to students or the general public through the use of various technologies (e.g., web-based services, Facebook sites). Based on these findings, it is reasonable to expect faculty development for online teaching may also vary by the Carnegie type of the institution.

\section{Value Placed on Faculty Development for Online Teaching}

The review of faculty development articles conducted earlier identified the training content and activities various institutions and authors used in particular situations. By the close of each article, author(s) were able to comment on the value of training opportunities by indicating whether the content or activity would be continued or modifications of the training pursued. One lack, therefore, in this literature is an understanding of the level of value placed on the content or activity, from a low level of value ranging to a high level of value. Author(s) of these articles commented only on the content or activities in their study, and not on a full list of possible options. This hole in the literature is addressed in the current study.

\section{Research Questions}

This study was designed to answer six research questions: 1) What content or topics are higher education institutions including in their faculty development for online teaching? 2) How or by what activity or format is the training offered? 3) Are there differences in the training content by the Carnegie type of the institution? 4) Are there differences in the training activity by the Carnegie type of the institution? 5) What value do the institutions place on the training content? 6) What value do they place on the training activity?

\section{METHODOLOGY}




\section{B. Research Design and Instrument}

This study is based on survey research that collected information from participating higher education institutions. As this is one of the first attempts to assess faculty development for online teaching practices in a national sample, survey research is an appropriate approach. Given that the study asked faculty development professionals at higher education institutions to describe and value various faculty development content and activities, it is essentially a descriptive study.

The instrument used was developed by the first author and was based on a thorough review of the published literature on faculty development for online teaching [1]. Once a draft of the instrument was made, the instrument was reviewed by the Sloan-C Advisory Panel for Faculty Satisfaction as well as representatives of the Sloan-C and WCET organizations, including organizational leaders and researchers, faculty developers, and faculty who conduct research on this topic. This review phase resulted in many additions and revisions, producing a cleaner and more comprehensive instrument. Finally, the survey was reviewed further by two experienced faculty development professionals to ensure item validity and instrument reliability.

This study used three major items from the instrument (the total survey included 26 items). First, institutions were surveyed regarding types of content included in faculty development sessions in 201112. For example, course management systems (CMS), blogs, wikis, podcasts, Facebook/Twitter, mobile pedagogies, advanced topics for experienced faculty, problem-based learning, experiential learning, critical thinking, use of case studies, creating community, student learning styles, Community of Inquiry (see http://communitiesofinquiry.com/), blended instruction, discipline-specific training, assessment of student learning, instructional design models, research base(s) of online learning). In addition, an openended window was available for individuals to add items not on this list.

Second, institutions were surveyed regarding the types of training activities used in faculty development sessions in 2011-12 - e.g., e-newsletter, one-on-one, hands-on, short session ( $<2$ hours), workshop (2-5 hours), one-time session, multiple sessions ( $2-5$ sessions), many sessions ( $>5$ sessions), summer semester training, year-long training, consortial (multi-institutional) training, webinars, online modules, peer training, train-the-trainer, create online course, peer review of course, use of instructional design students.

Third and fourth, for both items above, individuals were asked to indicate the value placed on the content or activity (see lists above) based on their professional experience. Value was defined by Likert-style definitions and was coded as follows: Extremely valuable (5), very valuable (4), somewhat valuable (3), less valuable (2), and not valuable (1).

Fifth, respondents were to indicate Carnegie classification of their institution if known. If not known, this item was to be left blank for the researcher to look up independently through the following link: http://classifications.carnegiefoundation.org/lookup_listings/institution.php.

The Institutional Review Board (IRB) at the University of Memphis reviewed and approved this research study.

\section{Population and Sample}

A request to complete the survey was sent from a Sloan-C officer to the official representations of higher education institutions that are members of the Sloan-C organization, or 407 members (which can include higher education institutions and systems as well as related businesses). The first author also sent a request to complete the survey to the online WCET Discussion Board, which is open to any individual who is an employee of a WICHE Cooperative for Educational Telecommunications (WCET) member organization, or approximately 295 members (which includes higher education institutions and businesses as well). The request asked that the survey information be forwarded to the individual responsible for faculty development at the institution. Because certain institutions are members of both organizations, the request asked institutions to beware of duplicative emails. Two items were included in the instrument (institution name and individual's name) so that duplicative responses could be identified and removed.

This sampling procedure was chosen to target institutions that, because of their membership in either 
Sloan-C or WCET, were most likely to have engaged in faculty development for online teaching. The results should not be generalized to all higher education institutions, especially not to institutions with no or little prior experience with online learning or faculty development for online teaching.

Responses were received from 48 institutions including 15 doctoral/research institutions, 14 master's institutions, five baccalaureate institutions, and 14 associate-level institutions. Responses from one special focus institution and one international institution were deleted from the analysis using Carnegie classifications in order to protect the anonymity of the responses. However, not all 48 institutions answered every question on the survey, so the number of institutions upon which results are based are noted throughout the results section.

The survey was completed by individuals located in Academic Affairs Offices (57.9\%), Chief Information (Technology) Offices (23.7\%), academic departments (18.4\%), academic colleges (13.2\%), and Central/System Offices (5.3\%). Respondents' titles included Coordinator, Director, Dean, and Vice President. This diversity of job titles and locations seems to imply that faculty development for online teaching is occurring in many different locations in institutions and under different guises or names.

\section{Data Collection}

The instrument was created within SurveyMonkey.com, which provides a flexible set of question types for the researcher as well as options for long-term data storage. The initial request to institutions for responses to the instrument was sent January 4, 2013, with a deadline for receipt of responses of February 1, 2013. On this date, the survey was closed to further responses and analysis began.

\section{E. Data Analysis}

For research question 1, "What content or topics are higher education institutions including in their faculty development for online teaching?" each of the 19 content types is presented as a frequency (number of institutions in the sample that provide this content) and the percent of the sample providing that content. For research question 2, "How or by what activity or format is the training offered?" each of the 18 training types is presented as a frequency (number of institutions in the sample that provide this activity) and the percent of the sample providing that type of training. A third column reports these results in rank order, from most frequently chosen to least frequent.

For research questions 3 and 4, "Are there differences in the training content or activity by the Carnegie type of the institution?" each of the 19 content types and 18 training types is reported by percent of institutions providing the content/activity in each Carnegie classification. A rank order is also reported within each separate Carnegie classification (research/doctoral, master's, baccalaureate, associate).

For research questions 5 and 6, "What value do they place on the training content or activity?" the Likert data are reported by each level of value as well as by calculated mean value for the training content (19 items) and training activity (18 items). Data are reported by mean value for each item and the number of institutions offering the content or activity.

\section{FINDINGS AND DISCUSSION}

\section{A. Training Offered}

\section{Training Content}

Table 1 presents the results from the survey on the content of training, by the number of institutional responses (or frequency), the percent of institutions this frequency represents), and the rank order in terms of frequency of responses. 
Table 1

Content of Training ( $\mathrm{n}=\mathbf{4 5}$ institutions)

\begin{tabular}{|c|c|c|c|}
\hline Content & Frequency & Percent of institutions & Rank \\
\hline $\begin{array}{l}\text { Assessment of student } \\
\text { learning }\end{array}$ & 44 & 97.8 & 1 \\
\hline Creating community & 41 & 91.1 & 2 \\
\hline $\begin{array}{l}\text { CMS } \\
\text { Student learning styles } \\
\text { Instructional design } \\
\text { model(s) }\end{array}$ & 38 & 84.4 & 3 (tie) \\
\hline $\begin{array}{l}\text { Advanced topics for } \\
\text { experienced faculty } \\
\text { Blended instruction }\end{array}$ & 37 & 82.2 & 4 (tie) \\
\hline Experiential learning & 33 & 73.3 & 5 \\
\hline Wikis & 32 & 71.1 & 6 \\
\hline Use of case studies & 30 & 66.7 & 7 \\
\hline $\begin{array}{l}\text { Blogs } \\
\text { Problem-based learning } \\
\text { Discipline-specific } \\
\text { training }\end{array}$ & 29 & 64.4 & 8 (tie) \\
\hline Mobile technologies & 28 & 62.2 & 9 \\
\hline Podcasts & 25 & 55.5 & 10 \\
\hline Critical thinking & 24 & 53.3 & 11 \\
\hline Facebook/Twitter & 23 & 51.1 & 12 \\
\hline $\begin{array}{l}\text { Research base(s) of } \\
\text { online learning }\end{array}$ & 22 & 48.9 & 13 \\
\hline Community of Inquiry & 21 & 46.7 & 14 \\
\hline
\end{tabular}

Several things may be concluded from a review of Table 1. First, there appears to be interesting consistency among institutions around the content areas. Assessment; creating community; and learning about the institution's CMS, student learning styles, and instructional design top the majority of institutions' reported content for faculty development for online teaching. Even a less-well-known instructional model such as the Community of Inquiry has been included in the training of $46.7 \%$ of the participating institutions.

Second, given the widespread use of mobile technologies (79\%) [33], as well as Facebook (85\%) and Twitter (27\%) [34], one might expect training on current topics or tools (e.g., mobile technologies at $62.2 \%$ or Facebook/Twitter at $51.1 \%$ ) to be prevalent. This may capture respondents' emphasis on matters of pedagogy rather than tools (more on this later), or it may simply be a case of capturing new training content at some mid-point in its adoption cycle. Third, less than half of the institutions provide faculty with information drawn from research on online learning. This may mean such findings are included but not labeled as such, or less value is placed on this type of information for faculty. It could also indicate that those developing the training materials are not aware of the availability of such research; this conclusion ought to be verified in further research.

Note that student learning styles - which are treated with some skepticism by some experts in the field such as Coffield, Moseley, Hall, and Ecclestone [35] - are treated by these faculty developers as knowledge worth sharing with faculty. Perhaps the faculty developers find learning styles helpful in orienting faculty to consider how students best learn, or they have opted to use them despite the criticism from the field. This issue needs further exploration.

\section{Training Activity}


Table 2 presents the results from the survey on the different activities of training, by the number of institutional responses (or frequency), the percent of institutions this frequency represents, and the rank order in terms of frequency of responses.

Table 2

Activities of Training ( $n=44$ institutions)

\begin{tabular}{|l|c|c|c|}
\hline Activity & Frequency & Percent of institutions & Rank \\
\hline Workshop (2-5 hours) & 44 & 100.0 & 2 (tie) \\
\hline $\begin{array}{l}\text { One-on-one training } \\
\text { Short session (<2 hours) }\end{array}$ & 43 & 97.7 & 3 \\
\hline $\begin{array}{l}\text { Hands-on training (in a } \\
\text { lab) }\end{array}$ & 42 & 95.5 & 4 \\
\hline Create online course & 41 & 93.2 & 5 \\
\hline One-time session & 40 & 90.1 & 7 \\
\hline $\begin{array}{l}\text { Multiple sessions (2-5 } \\
\text { sessions) }\end{array}$ & 39 & 88.6 & 8 \\
\hline Online modules & 38 & 86.4 & 11 (tie) \\
\hline Webinars & 37 & 84.1 & 12 \\
\hline Year-long training & 36 & 81.8 & 13 \\
\hline Peer training & 35 & 68.2 & 13 \\
\hline $\begin{array}{l}\text { Summer semester } \\
\text { training } \\
\text { Peer review of course }\end{array}$ & 30 & & 14 \\
\hline $\begin{array}{l}\text { Many sessions (>5 } \\
\text { sessions) }\end{array}$ & 26 & 59.1 & 16 \\
\hline E-newsletter & 24 & 54.5 & 25 \\
\hline Train-the-trainer & 23 & 52.3 & 25.0 \\
\hline $\begin{array}{l}\text { Consortial (multi- } \\
\text { institutional) training }\end{array}$ & 11 & 15.9 & \\
\hline $\begin{array}{l}\text { Use of instructional } \\
\text { design students }\end{array}$ & 7 & & \\
\hline
\end{tabular}

In Table 2, there is again great consistency among institutions in the use of various training activities. In fact, six activities-workshops (2-5 hours), one-on-one trainings, short sessions ( $<2$ hours), hands-on training (in a lab), creating an online course, and one-time sessions-are used by $90 \%$ of participating institutions. The widespread use of face-to-face training is particularly intriguing given the focus of the training on online delivery. Some of these top six activities may be a holdover from earlier faculty development efforts since they can be (and were likely) used to teach faculty skills that precede the interest in online learning. In other words, these activities may be tried-and-true development activities irrespective of the topic or focus of the training. Another interesting finding was that uniquely online methods for training faculty how to teach online (online modules, webinars) are less popular. These resources may be provided through other organizations, such as the Sloan-C Consortium, so it may not be fair to assume that these online training types are actually developed and offered by the institution. The data also show that training activities that take more effort (such as multiple sessions or many sessions) - on the part of the development staff as well as faculty-are less frequently used than the top six activities. Consortial training and use of instructional design students are infrequently used, most likely because a consortium is not available to the institution or an instructional design program is not offered by the institution.

Perhaps the most interesting finding is the frequent (93.2\% of institutions) request for faculty to create an 
online course during their faculty development. This may be due to the faculty member having greater motivation to learn in order to develop a course or the practicality of immediately applying what one is learning. In any case, having faculty develop an online course is a frequent development exercise, one that makes learning relevant to the faculty person and perhaps makes the skills easier to remember as well.

\section{B. Differences by Carnegie Classification}

\section{Training Content}

To improve the ease of comparing results among tables, the types of training content in Table 3 are presented in the same order as reported in Table 1. Rank is given for each type of training content for all institutions in the specific Carnegie classification.

Table 3

Differences in Content Used by Carnegie Type ( $n=45$ institutions)

\begin{tabular}{|c|c|c|c|c|c|c|c|c|}
\hline \multirow[b]{2}{*}{ Content } & \multicolumn{2}{|c|}{ Research/Doctoral } & \multicolumn{2}{|c|}{ Master's } & \multicolumn{2}{|c|}{ Baccalaureate } & \multicolumn{2}{|c|}{ Associate } \\
\hline & $\%$ & Rank & $\%$ & Rank & $\%$ & Rank & $\%$ & Rank \\
\hline $\begin{array}{l}\text { Assessment of } \\
\text { student learning }\end{array}$ & 93 & 2 & 100 & 1 & 100 & 1 & 100 & 1 \\
\hline $\begin{array}{l}\text { Creating } \\
\text { community }\end{array}$ & 100 & 1 & 83 & 4 & 100 & 1 & 92 & 2 \\
\hline CMS & 80 & 4 & 100 & 1 & 40 & 4 & 23 & 10 \\
\hline $\begin{array}{l}\text { Student learning } \\
\text { styles }\end{array}$ & 87 & 3 & 77 & 5 & 60 & 3 & 83 & 3 \\
\hline $\begin{array}{l}\text { Instructional } \\
\text { design model(s) }\end{array}$ & 80 & 4 & 92 & 2 & 100 & 1 & 75 & 5 \\
\hline $\begin{array}{l}\text { Advanced topics } \\
\text { for experienced } \\
\text { faculty }\end{array}$ & 87 & 3 & 92 & 2 & 60 & 3 & 83 & 3 \\
\hline $\begin{array}{l}\text { Blended } \\
\text { instruction }\end{array}$ & 87 & 3 & 85 & 3 & 80 & 2 & 75 & 5 \\
\hline $\begin{array}{l}\text { Experiential } \\
\text { learning }\end{array}$ & 73 & 5 & 69 & 6 & 60 & 3 & 77 & 4 \\
\hline Wikis & 67 & 6 & 69 & 6 & 40 & 4 & 67 & 6 \\
\hline Use of case studies & 80 & 4 & 62 & 7 & 60 & 3 & 58 & 7 \\
\hline Blogs & 60 & 7 & 69 & 6 & 20 & 5 & 42 & 9 \\
\hline $\begin{array}{l}\text { Problem-based } \\
\text { learning }\end{array}$ & 67 & 6 & 54 & 9 & 60 & 3 & 75 & 5 \\
\hline $\begin{array}{l}\text { Discipline-specific } \\
\text { training }\end{array}$ & 60 & 7 & 58 & 8 & 20 & 5 & 75 & 5 \\
\hline $\begin{array}{l}\text { Mobile } \\
\text { technologies }\end{array}$ & 67 & 6 & 62 & 7 & 40 & 4 & 67 & 6 \\
\hline Podcasts & 53 & 9 & 62 & 7 & 60 & 3 & 50 & 8 \\
\hline Critical thinking & 80 & 4 & 69 & 6 & 60 & 3 & 75 & 5 \\
\hline Facebook/Twitter & 53 & 9 & 62 & 7 & 20 & 5 & 75 & 5 \\
\hline $\begin{array}{l}\text { Research base(s) } \\
\text { of online learning }\end{array}$ & 80 & 4 & 58 & 8 & 20 & 5 & 42 & 9 \\
\hline $\begin{array}{l}\text { Community of } \\
\text { Inquiry }\end{array}$ & 57 & 8 & 46 & 9 & 20 & 5 & 50 & 8 \\
\hline
\end{tabular}


Table 3 shows teaching faculty how to assess student learning to be of consistent importance across Carnegie types. Also, while "discipline-specific training" might have been something of particular interest to institutions with strong disciplinary differences (e.g., research/doctoral institutions), it was much more common among the associate-level institutions.

Differences by Carnegie type were more common, from the low frequency (23\%) of CMS training among associate-level institutions to the higher frequency (57\%) of institutions including the Community of Inquiry among research/doctoral institutions. There is a difference to be teased out between the frequency in training for tools versus pedagogies that may be due to institutions' Carnegie types. If we focus on the lines comparing experiential learning (a pedagogy of learning) versus wikis (a tool), we notice both research/doctoral institutions and associate-level institutions place a higher value on the pedagogical training over the training dealing with a tool (in this case, a wiki is a software tool). Another example may suffice to illustrate this point. Compare the frequencies for podcasts (a delivery tool) and critical thinking (a pedagogy of learning); research/doctoral institutions and associate-level institutions seem to use the pedagogy more frequently than the tool. The one exception to this is, of course, the CMS, which is a tool that all online teachers must use irrespective of the pedagogies used in the course, although this tool seems less frequently the focus of training for associate-level institutions. Why associate-level institutions] may offer such training less frequently than all other training content in the survey is unknown; perhaps all community college faculty have already learned how to use the CMS although this must be explored further.

\section{Training Activity}

To improve the ease of comparing results among tables, the types of training content in Table 4 are presented in the same order as reported in Table 2. Rank is given to each type of training content for all institutions in the specific Carnegie classification.

Table 4

Differences by Carnegie Type ( $n=44$ institutions)

\begin{tabular}{|l|c|c|c|c|c|c|c|c|}
\hline \multirow{2}{*}{ Activity } & \multicolumn{2}{|c|}{ Research/Doctoral } & \multicolumn{2}{|c|}{ Master's } & \multicolumn{2}{c|}{ Baccalaureate } & \multicolumn{2}{c|}{ Associate } \\
\cline { 2 - 9 } & $\%$ & Rank & $\%$ & Rank & $\%$ & Rank & $\%$ & Rank \\
\hline $\begin{array}{l}\text { Workshop (2-5 } \\
\text { hours) }\end{array}$ & 100 & 1 & 85 & 3 & 75 & 2 & 92 & 2 \\
\hline $\begin{array}{l}\text { One-on-one } \\
\text { training }\end{array}$ & 100 & 1 & 100 & 1 & 100 & 1 & 92 & 2 \\
\hline $\begin{array}{l}\text { Short session (<2 } \\
\text { hours) }\end{array}$ & 100 & 1 & 100 & 1 & 100 & 1 & 100 & 1 \\
\hline $\begin{array}{l}\text { Hands-on training } \\
\text { (in a lab) }\end{array}$ & 87 & 2 & 100 & 1 & 100 & 1 & 100 & 1 \\
\hline $\begin{array}{l}\text { Create online } \\
\text { course }\end{array}$ & 100 & 1 & 92 & 2 & 100 & 1 & 83 & 3 \\
\hline One-time session & 87 & 2 & 100 & 1 & 75 & 2 & 100 & 1 \\
\hline $\begin{array}{l}\text { Multiple sessions } \\
\text { (2-5 sessions) }\end{array}$ & 100 & 1 & 77 & 4 & 75 & 2 & 92 & 2 \\
\hline Online modules & 87 & 2 & 85 & 3 & 0 & 6 & 92 & 2 \\
\hline Webinars & 80 & 3 & 85 & 3 & 75 & 2 & 92 & 2 \\
\hline Year-long training & 40 & 6 & 62 & 5 & 50 & 4 & 50 & 7 \\
\hline Peer training & 80 & 3 & 77 & 4 & 0 & 6 & 75 & 4 \\
\hline
\end{tabular}




\begin{tabular}{|l|c|c|c|c|c|c|c|c|}
\hline $\begin{array}{l}\text { Summer semester } \\
\text { training }\end{array}$ & 67 & 4 & 77 & 4 & 67 & 3 & 67 & 5 \\
\hline $\begin{array}{l}\text { Peer review of } \\
\text { course }\end{array}$ & 60 & 5 & 77 & 4 & 0 & 5 & 67 & 5 \\
\hline $\begin{array}{l}\text { Many sessions (>5 } \\
\text { sessions) }\end{array}$ & 80 & 3 & 50 & 6 & 50 & 4 & 58 & 6 \\
\hline E-newsletter & 80 & 3 & 28 & 8 & 75 & 2 & 50 & 7 \\
\hline Train-the-trainer & 33 & 7 & 46 & 7 & 67 & 3 & 83 & 3 \\
\hline $\begin{array}{l}\text { Consortial (multi- } \\
\text { institutional) trg. }\end{array}$ & 6 & 9 & 23 & 9 & 25 & 5 & 50 & 7 \\
\hline $\begin{array}{l}\text { Use of } \\
\text { instructional } \\
\text { design students }\end{array}$ & 13 & 8 & 23 & 9 & 0 & 6 & 17 & 8 \\
\hline
\end{tabular}

From a review of Table 4's results, we can ascertain several things. First, the same six activities receive the highest frequencies for all four Carnegie types. Differences are also evident. Research/doctoral institutions, with greater financial and personnel resources, seem to offer more of personnel-intensive activities such as multiple (2-5) sessions and many $(>5)$ sessions. Train-the-trainer models are used more frequently by associate-level institutions, which may capture a willingness, on the part of community college faculty, to learn from other faculty or it may capture a preference for a more cost-efficient use of training resources. Similarly, peer review of a course was less frequently used among research/doctoral institutions where faculty are, perhaps, more competitive and more likely to experience criticism from a peer as inadequate for one's prospects for promotion and tenure. Community colleges, often part of a state community college system that includes multiple campuses, used consortial training more frequently than the other Carnegie types. Lastly, the use of instructional design students - which might be a program offered at research/doctoral and master's institutions - was found more frequently by the master's institutions; perhaps this, too, is a reflection of the difficulty of faculty to accept help or criticism, especially from a student. In any case, these explanations draw upon known differences among Carnegie types and are offered as tentative insights only. Whether individuals involved in faculty development or their faculty participants would recognize (or agree with) these interpretations is another matter that awaits further exploration.

\section{Values Placed on Training}

\section{Training Content}

To improve comparability, the items in Table 5 are presented in the same order as in Tables 1 and 3 . The results presented in Table 5 give the percent of total institutions providing a value estimate of the training content; that is, the percentage includes only those institutions that offer the particular type of training, which explains why the number of institutions in the final column varies.

Table 5

Values Placed on Content by Percent of Total Institutions (n=\# of institutions offering content)

\begin{tabular}{|l|c|c|c|c|c|c|}
\hline Content & $\begin{array}{c}\text { Not } \\
\text { valuable }\end{array}$ & $\begin{array}{c}\text { Less } \\
\text { valuable }\end{array}$ & $\begin{array}{c}\text { Somewhat } \\
\text { valuable }\end{array}$ & $\begin{array}{c}\text { Very } \\
\text { valuable }\end{array}$ & $\begin{array}{c}\text { Extremely } \\
\text { valuable }\end{array}$ & $\begin{array}{c}\text { Mean } \\
\text { value }\end{array}$ \\
\hline $\begin{array}{l}\text { Assessment of } \\
\text { student learning }\end{array}$ & 0 & 0 & 68 & 50 & 43 & $\begin{array}{c}4.36 \\
\mathrm{n}=44\end{array}$ \\
\hline $\begin{array}{l}\text { Creating } \\
\text { community }\end{array}$ & 2 & 2 & 17 & 49 & 29 & 3.98 \\
$\mathrm{n}=41$
\end{tabular}




\begin{tabular}{|l|c|c|c|c|c|c|}
\hline $\begin{array}{l}\text { Student learning } \\
\text { styles }\end{array}$ & 3 & 14 & 25 & 44 & 14 & $\begin{array}{c}3.53 \\
\mathrm{n}=36\end{array}$ \\
\hline $\begin{array}{l}\text { Instructional design } \\
\text { model(s) }\end{array}$ & 0 & 3 & 18 & 47 & 32 & $\begin{array}{c}4.08 \\
\mathrm{n}=38\end{array}$ \\
\hline $\begin{array}{l}\text { Advanced topics } \\
\text { for experienced } \\
\text { faculty }\end{array}$ & 0 & 3 & 18 & 54 & 21 & $\begin{array}{c}3.77 \\
\mathrm{n}=39\end{array}$ \\
\hline Blended instruction & 0 & 5 & 19 & 54 & 22 & $\begin{array}{c}3.92 \\
\mathrm{n}=37\end{array}$ \\
\hline $\begin{array}{l}\text { Experiential } \\
\text { learning }\end{array}$ & 0 & 6 & 18 & 55 & 15 & 3.61 \\
\hline Wikis & 0 & 34 & 45 & 21 & 0 & $\begin{array}{c}2.86 \\
\mathrm{n}=29\end{array}$ \\
\hline Use of case studies & 0 & 3 & 33 & 47 & 17 & 3.77 \\
$\mathrm{n}=30$
\end{tabular}

Several things may be gleaned from Table 4. First, all of the training content can be claimed to be at least "somewhat valuable." Second, the highest values seem to be reserved for issues dealing with pedagogies, from experiential learning to problem-based learning to critical thinking. Third, training content that seems to be oriented to using a tool (be it the CMS, a wiki, blog, podcasts, and even Facebook/Twitter) has a lower mean value than some of the more pedagogical content. (This should not be construed to mean that using a wiki has no pedagogical implications, but only that wikis seem to be grouped among the tools, rather than the higher-valued pedagogies.) It may be fair to conclude that these faculty developers value teaching pedagogy (which is linked to learning theories), and view the manipulation of tools to be less important to, or more supportive of, the pedagogical choices and learning objectives of the course.

\section{Training Activity}

To improve comparability, the items in Table 6 are presented in the same order as in Tables 2 and 4.The results presented in Table 6 give the percent of total institutions providing a value estimate of the training content; that is, the percentage includes only those institutions that offer the particular type of training, 
which explains why the number of institutions in the final column varies.

Table 6

Values Placed on Activity by Percent of Total Institutions (n=\# of institutions offering activity)

\begin{tabular}{|c|c|c|c|c|c|c|}
\hline Activity & $\begin{array}{c}\text { Not } \\
\text { valuable }\end{array}$ & $\begin{array}{c}\text { Less } \\
\text { valuable }\end{array}$ & $\begin{array}{c}\text { Somewhat } \\
\text { valuable }\end{array}$ & $\begin{array}{c}\text { Very } \\
\text { valuable }\end{array}$ & $\begin{array}{l}\text { Extremely } \\
\text { valuable }\end{array}$ & $\begin{array}{l}\text { Mean } \\
\text { value }\end{array}$ \\
\hline Workshop (2-5 hours) & 0 & 5 & 10 & 40 & 45 & $\begin{array}{l}4.25 \\
\mathrm{n}=40\end{array}$ \\
\hline One-on-one training & 0 & 2 & 2 & 37 & 58 & $\begin{array}{l}4.60 \\
n=43\end{array}$ \\
\hline $\begin{array}{l}\text { Short session }(<2 \\
\text { hours) }\end{array}$ & 0 & 2 & 5 & 49 & 44 & $\begin{array}{l}4.35 \\
\mathrm{n}=43\end{array}$ \\
\hline $\begin{array}{l}\text { Hands-on training (in } \\
\text { a lab) }\end{array}$ & 0 & 2 & 5 & 45 & 48 & $\begin{array}{l}4.38 \\
\mathrm{n}=42 \\
\end{array}$ \\
\hline Create online course & 0 & 0 & 2 & 46 & 46 & $\begin{array}{l}4.37 \\
\mathrm{n}=41\end{array}$ \\
\hline One-time session & 0 & 13 & 15 & 50 & 23 & $\begin{array}{r}3.83 \\
\mathrm{n}=40 \\
\end{array}$ \\
\hline $\begin{array}{l}\text { Multiple sessions (2-5 } \\
\text { sessions) }\end{array}$ & 0 & 3 & 13 & 59 & 21 & $\begin{array}{l}3.82 \\
\mathrm{n}=39\end{array}$ \\
\hline Online modules & 0 & 5 & 21 & 45 & 29 & $\begin{array}{l}3.97 \\
\mathrm{n}=38\end{array}$ \\
\hline Webinars & 0 & 19 & 41 & 33 & 8 & $\begin{array}{l}3.30 \\
\mathrm{n}=37\end{array}$ \\
\hline Year-long training & 0 & 9 & 14 & 55 & 23 & $\begin{array}{l}3.91 \\
\mathrm{n}=22\end{array}$ \\
\hline Peer training & 0 & 3 & 26 & 43 & 29 & $\begin{array}{l}3.97 \\
\mathrm{n}=35 \\
\end{array}$ \\
\hline $\begin{array}{l}\text { Summer semester } \\
\text { training }\end{array}$ & 0 & 3 & 30 & 47 & 20 & $\begin{array}{l}3.83 \\
\mathrm{n}=30 \\
\end{array}$ \\
\hline Peer review of course & 0 & 3 & 13 & 47 & 37 & $\begin{array}{l}4.17 \\
\mathrm{n}=30\end{array}$ \\
\hline $\begin{array}{l}\text { Many sessions (>5 } \\
\text { sessions) }\end{array}$ & 0 & 8 & 23 & 42 & 27 & $\begin{array}{l}3.88 \\
n=26\end{array}$ \\
\hline E-newsletter & 4 & 0 & 54 & 17 & 17 & $\begin{array}{l}3.46 \\
n=24\end{array}$ \\
\hline Train-the-trainer & 4 & 4 & 30 & 43 & 17 & $\begin{array}{l}3.65 \\
n=23\end{array}$ \\
\hline $\begin{array}{l}\text { Consortial (multi- } \\
\text { institutional) trg. }\end{array}$ & 0 & 27 & 18 & 45 & 9 & $\begin{array}{l}3.36 \\
\mathrm{n}=11\end{array}$ \\
\hline $\begin{array}{l}\text { Use of instructional } \\
\text { design students }\end{array}$ & 14 & 14 & 0 & 43 & 29 & $\begin{array}{l}3.57 \\
\mathrm{n}=7\end{array}$ \\
\hline
\end{tabular}

Four things may be concluded from a review of the results in Table 6. First, there is greater consistency among those completing the survey regarding the value of activities offered than the types of content displayed in Table 5. Second, the "tried-and-true" activities of short sessions, workshops, one-on-one training, and hands-on training receive the highest marks. Third, two additional activities-having the faculty person create an online course and peer review of that course once designed-are also highly regarded. These latter activities force the faculty person to become actively involved in not only developing his/her course but to see the developed course through the eyes of an outsider (in this case a 
peer, representing a student entering the course for the first time). Fourth, it is intriguing that two relatively new training activities are valued so differently; the webinar receives the lowest mean value (3.30), while online modules receive a much higher mean value (3.97). Is a webinar a more passive form of the short session training and the online module an instructional technique that demands more involvement and attention on the part of the participant? Future research should explore the faculty's perception of these training forms as their insight may tell us which training types they value and why they find it valuable, or not. In any case, this bears further exploration as there may be a difference that matters for future faculty development efforts.

It might be useful to compare the findings in Tables 5 and 6 for a moment. First, it appears greater value is placed on many of the activities used by trainers in Table 6 and less agreement, relatively speaking, regarding the value of various content types for training in Table 5. Perhaps this simply reflects maturation in the field of faculty development around using common activities and a knowledge of which activities work best, as well as more volatility or inconsistency in the content areas. Perhaps the contents of training change too often, such as specific tools, or perhaps the field is split between teaching tools versus teaching pedagogy. In any case, the differences between how institutions use and value content and activities of training certainly bear further research and analysis.

\section{RECOMMENDATIONS}

It is important to first note that faculty development for online teaching may well be a rapidly changing field that must continuously evolve its offerings (especially dealing with new tools) and that this study is a one-time view of what work was being done in 2011-12. With these data and results, one continuing question that must be asked is how the field is changing and why. It is likely that in the future, the budgets of higher education institutions will affect leaders' decisions regarding the allocation of resources and, as a result, new faculty will likely arrive at the professoriate with some rudimentary skills and understanding of online learning. Perhaps the pressures to offer online learning will subside, although there are no signs of this being the case at the current time.

Certainly, we can say that our faculty developers are focused primarily on helping faculty gain the skills and understanding to improve student learning as they enroll in online coursework. They focus on known pedagogies - e.g., experiential learning, critical thinking - that have been proven effective in the face-toface classroom and transferred successfully to the online environment. They focus on traditional training activities - e.g., the short session, one-on-one training-even as they explore new models of training. Similarly, faculty developers are exploring new training content (Facebook/Twitter) and training activities (online modules) which result in some understandable differences by Carnegie type (e.g., the use of instructional design students at institutions offering an instructional design program).

What will be interesting to explore in the future are some of the tentative interpretations of the data made herein, which require further research to determine the real cause of the phenomenon. Do faculty developers tend to prefer pedagogy over tools (or to subjugate the use of tools to pedagogy)? And how do faculty participating in development activities view the value of pedagogy versus the tool? Do faculty also prefer learning how to help students learn, and then explore the different tools which might bring learning about?

The lack of value placed on research in online learning lends itself to several interpretations and perhaps as many causes. These need to be explored with faculty developers as well as faculty to determine how research can be made more acceptable to both trainers and trainees. Is it a failing of the research and our ability to explain its implications for faculty and faculty developers? In that case, perhaps journals such as $J A L N$ can ask authors to provide these connections, if appropriate, in manuscripts submitted for consideration. This quandary created by the low value placed on research leads to an important set of questions to be tackled by faculty developers. Since educating faculty is the reason for faculty development, it is important to recognize that faculty can create limits to what faculty developers can accomplish. Faculty developers might find some faculty lacking interest or motivation to learn about 
learning theories, pedagogies, or online learning research, because these may be associated with either colleges of education or teaching duties that may be less valued than research. It could be that lack of attendance at faculty training events reflect the heavy demands placed on faculty time rather than reflecting on the value of development. In either case, two important cautions should be made. Faculty are not a homogenous group, and it is likely that many faculty members have the curiosity, interest, and drive to become better teachers in their online courses. Some faculty may well appreciate learning how to teach better and why some tactics work and others do not. Disparaging remarks made by some faculty should not preclude offering others the opportunity to learn.

The limits stated above need not be the end of the matter: limits often encourage creativity and new approaches. Perhaps facing and dealing with these limits will do the same for faculty developers, generating new ideas for addressing faculty beliefs, some of which will be successful and others not. In time, with effort, new approaches may be developed that help faculty appreciate the value of both faculty development and online teaching (as well as learning from online learning research). These thoughts might well be hovering in some practitioner's mind right now and need to be implemented, evaluated, and shared so that others may test those approaches in their institutions. As a field of experienced professionals, faculty developers are not without the creative resources to turn these limits into more productive and effective faculty development efforts in the future. Professional development is important for all practitioners; by providing faculty with more information in how to teach effectively, institutions can help create greater faculty satisfaction in the online classroom.

\section{ABOUT THE AUTHORS}

Dr. Katrina Meyer is currently professor of higher and adult education at The University of Memphis specializing in online learning and higher education. She is the author of Lessons Learned from Virtual Universities, a 2009 publication in the New Directions in Higher Education series, and Cost-Efficiencies of Online Learning, a 2006 publication of the ASHE Higher Education Report Series. For over three years, she was Director of Distance Learning and Technology for the University and Community College System of Nevada. Prior to this, she served over 8 years as Associate Director of Academic Affairs for the Higher Education Coordinating Board in the state of Washington and was responsible for technology planning and policy related to online learning.

Dr. Vicki Murrell is on the faculty in the department of counseling, educational psychology and research at the University of Memphis. She previously served as the Assistant Dean for Online Education at the University of Memphis, providing administrative oversight, faculty development, and instructional guidance in the development of the UMOnline program, which offers more than 40 online degrees and certificates. Dr. Murrell spent over 20 years in educational administration focused on the integration of technology into curricula, at all levels of elementary, secondary, undergraduate, graduate, and professional education.

\section{REFERENCES}

1. Meyer, K.A. An analysis of the research on faculty development for online teaching and identification of new directions. Journal of Asynchronous Learning Networks, 17:93-112 (2014).

2. Sloan Consortium. Quality framework narrative, the 5 pillars. http://sloanconsortium.org/5pillars

3. Grant, M.M. Learning to teach with the web: Factors influencing teacher education faculty. Internet and Higher Education, 7:329-341 (2004).

4. Hixon, E., Barczyk, C., Buckenmeyer, J., \& Feldman, L. Mentoring university faculty to become high quality online educators: A program evaluation. Online Journal of Distance Learning Administration,14(5):

http://www.westga.edu/ distance/ojdla/winter144/hixon_Barczyk_Buckenmeyer_feldman144.html 
5. Kukulska-Hulme, A. How should the higher education workforce adapt to advancements in technology for teaching and learning? Internet and Higher Education, 15(4): 247-254 (2012).

6. Lackey, K. Faculty development: An analysis of current and effective training strategies for preparing faculty to teach online. Online Journal of Distance Learning Administration, 14(5): (2011). http://www.westga.edu/ distance/ojdle/winter144/lackey144.html

7. Vaill, A.L., \& Testori, P.A. Orientation, mentoring and ongoing support: A three-tiered approach to online faculty development. Journal of Asynchronous Learning Networks, 12(1): 111-120 (2012).

8. Daly, C.J., \& Dee, J.R. Innovative models for organizing faculty development programs: Pedagogical reflexivity, student learning empathy, and faculty agency. Human Architecture: Journal of the Sociology of Self-Knowledge, 7(1): 1-22 (2009).

9. Kane, S.A. Interdisciplinary faculty development seminar: A model for learning emerging technologies while developing interdisciplinary partnerships. Journal of Science Education and Technology, 12(4): 421-430 (2003).

10. Ragan, L.C., Bigatel, P.M., Kennan, S.S., \& Dillon, J.M. From research to practice: Towards the development of an integrated and comprehensive faculty development program. Journal of Asynchronous Learning Network, 16(5), 71-86 (2012).

11. Schrum, L., Burbank, M.D., Engle, J., Chambers, J.A., \& Glassett, K.F. Post-secondary educators' professional development: Investigation of an online approach to enhancing teaching and learning. Internet and Higher Education, 8: 279-289 (2005).

12. Chen, B., Sugar, A., \& Bauer, S. Effective faculty development through strategies for engagement and satisfaction. Educause Review, Sep/Oct (2012).

13. Dittmar, E., \& McCracken, H. Promoting continuous quality improvement in online education: The META model. Journal of Asynchronous Learning Networks, 12(1): 163-176 (2012).

14. Reilly, J., Vandenhouten, C., \& Gallagher-Lepak, S. Faculty development for e-learning: A multi-campus community of practice (COP) approach. Journal of Asynchronous Learning Networks, 12(1): 99-110 (2012).

15. Puzziferro., M., \& Shelton, K. A model for developing high-quality online courses: Integrating a systems approach with learning theory. Journal of Asynchronous Learning Networks, 12(3-4): 119136 (2008).

16. DeNoyelles, A., Cobb, C., \& Lowe, D. Influence of reduced seat time on satisfaction and perception of course development goals: A case study in faculty development. Journal of Asynchronous Learning Networks, 12(1): 85-98 (2012).

17. Johnson, T., Wisniewski, M.A., Kuhlemeyer, G., Isaacs, G., \& Krzykowski, J. Technology adoption in higher education: Overcoming anxiety through faculty bootcamp. Journal of Asynchronous Learning Networks, 12(1): 63-72 (2012).

18. Orozcco, M., Fowkles, J.K., Jerzak, P., \& Musgrove, A. Zero to sixty plus in 108 days: Launching a central elearning unit and its first faculty development program. Journal of Asynchronous Learning Networks, 12(1): 177-192 (2012).

19. Herman, J.H. Faculty development programs: The frequency and variety of professional development programs available to online instructors. Journal of Asynchronous Learning Networks,16(5), 87-102 (what year?). [Need to update year]

20. Diaz, V. Cloud-based technologies: Faculty development, support, and implementation. Journal of Asynchronous Learning Networks, 15(1): 95-102 (2011).

21. Major, C.H., \& Palmer, B. Reshaping teaching and learning: The transformation of faculty pedagogical content knowledge. Higher Education, 51(4): 619-647 (2006).

22. Lobel, M., Neubauer, M., \& Swedburg, R. Elements of group interaction in a real-time synchronous online learning-by-doing classroom without F2F participation. USDLA Journal, 16: (2002). http://www.usdla.or/html/journal/APR02_issue/article01.html

23. Meyer, K.A. \& McNeal, L.. How online faculty improve student learning productivity. Journal of Asynchronous Learning Networks, 15(3): (2011). 
24. Haviland, D., Shin, S., \& Turley, S. Now I'm ready: The impact of a professional development initiative on faculty concerns with program assessment. Innovative Higher Education, 35(4): 261275 (2010).

25. Koehler, M.J., Mishra, P., Hershey, K., \& Peruski, L. With a little help from your students: A new model for faculty development and online course design. Journal of Technology and Teacher Education, 12(1): 25-55 (2004).

26. Lavoie, D., \& Rosman, A.J. Using active student-centered learning-based instructional design to develop faculty and improve course design, delivery, and evaluation. Issues in Accounting Education, 22(1): 105-118 (2007).

27. Meyer, K.A. The "virtual face" of institutions: What do home pages reveal about higher education? Innovative Higher Education, 33(3), 141-157 (2008).

28. Meyer, K.A. The "virtual face" of institutions: Why legislators and other outsiders view higher education as aloof. The Internet and Higher Education, 11(3-4), 178-185 (2008).

29. Wilson, J. L., \& Meyer, K.A. Higher education websites: The "virtual face" of diversity. Journal of Diversity in Higher Education, 2(2), 91-102 (2009).

30. Jones, S.J., \& Meyer, K.A. The "virtual face" of distance learning at public colleges and universities: What do websites reveal about student support services? Online Journal of Distance Learning Administration, 15(4) http://www.westga.edu/ distance/ojdla/winter154/jones_meyer154.html

(2012).

31. Duggan, M., \& Brenner, J. The demographics of social media users - 2012. Pew Research Center, 2013.

32. Smith, A. Smartphone ownership 2013. Pew Research Center, 2013.

33. Coffield, F., Moseley, D., Hall, E., \& Ecclestone, K. Learning styles and pedagogy in post-16 learning: a systematic and critical review. LSRC reference. London: Learning \& Skills Research Centre, $2004 . \quad$ Retrieved from http://lerenleren.nu/bronnen/Learning\%20styles\%20by\%20Coffield\%20e.a..pdf.) 